\title{
Correction: Sustained AAV9-mediated expression of a non-self protein in the CNS of non-human primates after immunomodulation
}

\author{
Arlene I. Ramsingh, Steven J. Gray, Andrew Reilly, Michael Koday, Debbie Bratt, Merika \\ Treants Koday, Paul Munson, Robert Murnane, Jeremy Smedley, Yuhui Hu, Anne Messer, \\ Deborah Heydenburg Fuller
}

Dr. Paul Munson should be included in the author byline. He should be listed as the seventh author, and his affiliation is 6: the Department of Microbiology, University of Washington, Seattle, Washington, United States of America. The contributions of the author are as follows: Data curation, formal analysis, methodology, and validation.

\section{Reference}

1. Ramsingh Al, Gray SJ, Reilly A, Koday M, Bratt D, Koday MT, et al. (2018) Sustained AAV9-mediated expression of a non-self protein in the CNS of non-human primates after immunomodulation. PLoS ONE 13(6): e0198154. https://doi.org/10.1371/journal.pone.0198154 PMID: 29874260

\section{G OPEnACCess}

Citation: Ramsingh Al, Gray SJ, Reilly A, Koday M, Bratt D, Koday MT, et al. (2018) Correction: Sustained AAV9-mediated expression of a non-self protein in the CNS of non-human primates after immunomodulation. PLOS ONE 13(11): e0207077. https://doi.org/10.1371/journal.pone.0207077

Published: November 1, 2018

Copyright: ๑ 2018 Ramsingh et al. This is an open access article distributed under the terms of the Creative Commons Attribution License, which permits unrestricted use, distribution, and reproduction in any medium, provided the original author and source are credited. 